\title{
DETECTION OF VIRULENCE GENES IN ESCHERICHIA COLI STRAINS ISOLATED FROM DIARRHEIC AND HEALTHY FECES OF DAIRY CALVES IN BRAZIL
}

\section{C. de Moura, M. Ludovico, G.F. Valadares, M.S.V. Gatti, D.S. Leite}

Universidade de Campinas, Instituto de Biologia, Departmento de Microbiologia e Imunologia, CP 6109, CEP 13083-970, Campinas, SP, Brazil. E-mail: cmoura.bio@gmail.com

\begin{abstract}
The aim of this work was to test 101 strains of $E$. coli for virulence factors associated with enterotoxigenic and enterohemorrhagic pathotypes of E. coli isolated from diarrheic and non-diarrheic calves. The virulence factors of E. coliStx1 (Shiga toxin), Stx2, Ehly (Enterohemolysin), the eae gene, LT-II (heat-labile enterotoxin), STa (heat-stable toxin), and adhesins K99 and F41 were detected by PCR. Serogroups were determined by serological methods and Stx production was observed by biological assays in Vero cells. The frequency of the eae gene was higher in isolates from diarrheic calves $(35 / 58,60.3 \%)$ than in non-diarrheic calves $(8 / 43,18.6 \% ; P<0.001)$. The gene for Stx1 occurred at high frequencies in the diarrheic strains $(24 / 58,41.3 \%)$ as well as in non-diarrheic $(19 / 43$, $44.2 \%$ ) ones and all strains that were Stx positive by PCR showed cytotoxicity in Vero cells. Stx2 was found in ten strains, Ehly in eight strains, and LT-II in only two strains. Twenty-eight strains were negative for all of the PCR assays, including for F41 and K99 adhesins. The serogroups O7, $\mathrm{O} 23, \mathrm{O} 4, \mathrm{O} 8, \mathrm{O} 153$ and $\mathrm{O} 156$ were observed most frequently. Our results show that strains of $E$. coli isolated from cattle have similar virulence factors genes to strains isolated from cases of diseases in humans and may be a source of potentially pathogenic STEC for humans.
\end{abstract}

KEY WORDS: Escherichia coli, diarrhea, cattle, PCR, shiga toxin.

\section{RESUMO}

DETECÇÃO DE GENES DE VIRULÊNCIA EM AMOSTRAS DE ESCHERICHIA COLI ISOLADAS DE FEZES DE BEZERROS COM E DIARREIA NO BRASIL. O objetivo deste trabalho foi detectar em 101 amostras de $E$. coli isoladas de bezerros com e sem diarreia, fatores de virulência associados aos patotipos de E. coli enterotoxigênica e enterohemorrágica. Os fatores de virulência de E. coli Stx1 (Shiga toxina), Stx2, Ehly (Enterohemolisina), o gene eae, LT-II (enterotoxina termolábil), STa (toxina termo-estável), e adesinas K99 e F41 foram detectados por PCR. Os sorogrupos foram determinados por métodos sorológicos e a produção de Stx foi observada através de ensaios biológicos em células Vero. A frequência de detecção do gene eae foi maior nos isolados de bezerros com diarreia $(35 / 58,60,3 \%)$ do que em bezerros saudáveis $(8 / 43,18,6 \% ; P<0.001)$. O gene da toxina Stx1 foi detectado em alta frequência em amostras diarreicas $(24 / 58,40,3 \%)$, bem como em amostras não diarréicas (19/43,44,2\%) e todas as amostras positivas para toxina Stx em PCR mostraram citotoxicidade em células Vero. Stx2 foi encontrada em dez amostras, Ehly em oito amostras, e LT-II em duas amostras. Vinte e seis amostras foram negativas para todos os ensaios de PCR, incluindo para as adesinas F41 e K99. Os sorogrupos O7, O23, O4, O8, O153 e O156 foram detectados com maior frequência. $O$ trabalho mostra que amostras de $E$. coli isoladas de bovinos apresentam fatores de virulência semelhantes à isolados de casos de doenças em humanos e possivelmente é uma fonte para STEC potencialmente patogênicas para humanos.

PALAVRAS-CHAVE: Escherichia coli, diarreia, bovinos, PCR, shiga toxina.

Escherichia coli are common facultative anaerobic bacteria found in the gastrointestinal tract of warm-blooded animals and humans. Although most E. coli are harmless symbionts, pathogenic strains are associated with a range of diseases of zoonotic importance. Currently, there are at least six recognized enteropathogenic $E$. coli pathotypes that cause gastrointestinal disease: enteroaggregative(EaggEC), diffusely adherent (DAEC), enteropathogenic (EPEC), enterotoxigenic (ETEC), enteroinvasive (EIEC) and enterohemorrhagic (EHEC), where are included the shigatoxigenic E. coli (STEC) (GÜLER et al., 2008).

Diarrhea in calves is commonly caused by ETEC containing mainly K99 (F5), F41, and a heat-stable (STa) and a heat-labile enterotoxin (LT-II) as virulence 
factors (GÜLER et al., 2008). Ruminants, especially cattle, are known to be the most important reservoir ofSTEC. Food of cattle origin, especially undercooked meat and raw milk, are among those implicated in foodborne outbreaks of STEC. These strains may produce two types of Shiga toxin (Stx1 and Stx2) (Cobbold; Desmarchelier, 2001; Karmali et al., 2010). STEC isolates from diarrheic calves frequently have an associated virulence factor that elicits an attaching and effacing (A/E) lesion of the intestinal mucosa, a phenotype that requires a functional eae chromosomal gene and enterohemolysin (Ehly) production. These strains are known as EHECs (PATON; PATON, 1998). EHECO157is an important pathogeninindustrialized countries, but serogroups of $E$. coli, such as O26, O91, $\mathrm{O} 111$ and $\mathrm{O} 113$, are considered emergent pathogens associated with hemolytic uremic syndrome and hemorrhagic colitis (IRINO et al., 2005; ARYA et al., 2008; KARMALI et al., 2010).

The Brazilian bovine population is comprised of approximately 200 million animals (beef and dairy) in different states of the country (LEOMIL et al., 2003). Litter data are available about the occurrence and characteristics of STEC isolated from calves in many federation states (LEOMIL et al., 2003). The aim of this study was to determine the frequency of genetic virulence determinants among E. coli isolated from diarrheic and non-diarrheic calves from different dairy farms from Londrina, Paraná State, Brazil using molecular and biological methods.
Fifty-eight $E$. coli strains isolated from 29 diarrheic calves and 43 isolated from 21 healthy animals were used in this study. The strains were obtained from calves less than 3 months old from dairy farms in Londrina, Paraná State (Brazil) during the period of September 1998 to March 1999. E. coli strains 152-2(5) (eae/Stx1/Stx2), C3888 (Ehly) and ETEC23 (STa/LT-II/F41/K99), were used as positive controls, and E. coli DH5a was the negative control in all of the tests.

All E. coli isolates were screened for the presence of the genes using specific primers for eae (Yu; KAPER, 1992), Stx1 and Stx2 (OJENIYI et al., 1994), Ehly (PAton; PAton, 1998), STa (SO; MCCARTY, 1980), LT-II (Schultsz et al., 1994), K99 (RoosendaAl et al., 1984) and F41 (FIDOCK et al., 1989) using PCR. Bacterial DNA analysis was obtained after suspension from Triptoy Soy Agar (TSA) (Gibco) culture in $200 \mu \mathrm{L}$ of pure water and boiling at $100^{\circ} \mathrm{C}$ for $10 \mathrm{~min}$. The PCR assay was carried out in a total volume of 50 $\mu \mathrm{L}$ of mixture containing PCR buffer (Promega), 2 $\mathrm{mM} \mathrm{MgCl}, 0.2 \mathrm{mM}$ dNTPs, $60 \mathrm{ng}$ of each virulence gene-specific primer, 1.5UTaq polymerase(Promega) and $7 \mu \mathrm{LDNA}$ template. The amplification conditions included 30 cycles of denaturation at $94^{\circ} \mathrm{C}$ for $1 \mathrm{~min}$, annealing at a primer-specific temperature for $1 \mathrm{~min}$ and extension at $72^{\circ} \mathrm{C}$ for $1 \mathrm{~min}$, and a final extension at $72^{\circ} \mathrm{C}$ for $7 \mathrm{~min}$. The products were analyzed by electrophoresis on a $1.5 \%$ agarose gel. The gel was stained with ethidium bromide and photographed.

Table 1 - Virulence genes and serogroups of Escherichia coli isolated from diarrheic and non-diarrheic dairy calves in Londrina, Brazil, from September 1998 till March 1999.

\begin{tabular}{lcl}
\hline & \multicolumn{1}{c}{ Strains isolated from diarrheic calves } \\
\hline VirulenceFactor & No isolates & Serogroups (no. isolates) \\
\hline Eae & 16 & O1(1), O3(1), O7(1), O8(2), O17(1), O23(3), O78(1), O144(1), O146(1), O153(2), ONT(2) \\
Stx1 & 6 & O1(1), O10(1), O103(2), ONT(1), Rugous(1) \\
LT-II & 1 & Rugous(1) \\
eae/Stx1 & 14 & O23(1), O26(1), O55(2), O103(1), O117(1), O123(1), O124(1), O144(1), O146(2), ONT(2), \\
eae/Stx2 & 2 & O8 $(2)$ \\
eae/Ehly & 2 & O26(1), Rugous(1) \\
Stx1/Stx2 & 2 & O7(1), O153(1) \\
Stx1/LT-II & 1 & Rugous(1) \\
eae/Stx1/Ehly & 1 & ONT(1) \\
\hline & & \multicolumn{1}{c}{ Strains isolated from healthy calves } \\
\hline Eae & 2 & O156(1), O175(1) \\
Stx1 & 12 & O7(4), O15(2), O128(1), O153(1), O175(1), ONT(3) \\
Stx2 & 4 & O23(1), ONT(1), O119(1), Rugous(1) \\
eae/Stx1 & 3 & O4(1), O123(2) \\
eae/Ehly & 1 & O156(1) \\
Stx1/Stx2/Ehly & 1 & O113(1) \\
eae/Stx1/Ehly & 2 & O156(1) \\
Stx1/Stx2 & 1 & Rugous(1) \\
\hline - 13 isolates of diarrheic calves and 15 isolates from healthy calves were negative for all of the virulence factors. All of \\
the strains were negative for K99, F41 and STa.
\end{tabular}


Enterohemolysin (Ehly) was phenotypically detected on washed sheep blood agar plates (5\%) according to Beutin et al. (1988). All the stx-positive strains by PCR were tested for biological activity using cytotoxicity assays (CERQueIrA et al., 1999). Briefly, E. coli strains were cultured for 18 hours with continuous shaking at $37^{\circ} \mathrm{C}$ in tryptone soy broth (Gibco) and filter-sterilized supernatants were used in a confluent monolayer of Vero cells. The $O$ antigen of $E$. coli isolates was determined using the $\mathrm{O}$ antiserum (O1-O181) collection produced in the Reference Laboratory of Escherichia coli (LREC, Lugo, Spain) with microtechnique protocol described previously by BLANCO et al. (1992).

The chi-square $\left(\mathrm{X}^{2}\right)$ test and Fisher's exact test were used to assess significant differences about the association between diarrheic and healthy groups and the presence of virulence factors investigated in E. coli. Statistical significance was set at $P<0.05$.

Overall, 49 of the $101(48.5 \%)$ E. coli strains from calves carried the Shiga toxin gene. The Stx1 gene occurred at high frequencies in the diarrheic strains $(24 / 58,41.3 \%)$ as well as in non-diarrheic strains $(19 / 43,44.2 \% ; P>0.05)$ (Table 1$)$. All of the st $x$-positive strains by PCR were also cytotoxic in Vero cell assays. A total of 43 (42.5\%) strains were eae-positive and its frequency was higher in diarrheic calves $(35 / 58,60.3 \%)$ than in healthy calves $(8 / 43$, $18.6 \% ; P<0.001)$. The eae-positive strains were in some cases Stx1-positive (20 isolates), Stx2-positive (two isolates) and Ehly-positive (seven isolates). Ehly was detected phenotypically. The gene for LT-II was only detected in two isolates. All of the strains were negative for STa, K99 and F41 by PCR (Table 1). Of the 101 strains of $E$. coli analyzed, 21 were not typable, seven were rugous and 73 belonged to 35 different serogroups (Table 1).

Studies of the virulencefactors produced by E. coli strains in farm animals are relevant mainly because colibacillosis is an important cause of economic loss on farms. At the same time, E. coli isolated from animals may also have genes related to virulent strains for humans, zoonoses-associated or not (LeOMIL et al., 2003). In this report we identified only two strains with the gene for LT-II and it is not common in calves. On the other hand, the absence of these virulence genes indicated for negative ETEC in calves (AIDAR-UGRINOvich et al., 2007).

E. coli producing Shiga toxins and carrying the eae gene are commonly isolated from the feces of healthy calves and cattle (AIDAR-UGRINOVICH et al., 2007). In this study, the frequency of identification was not different between healthy and diarrheic strains, and in both groups, we found this gene at a high frequency $(\mathrm{P}>0.05)$ (Table1). However, theassociation of eae and stx gene found was in higher amounts among diarrheic strains than healthy strains. These associations and the occurrence of diseases in calves is not definitive. Güler et al. (2008) on Turkey, was showed that $13.5 \%$ and $5.4 \%$ of $E$. coli isolated from diarrheic calves presented $S t x 1$ and Stx 2 , respectively. However, in other study, none E. coli isolated from healthy calves was positive for the genes associated with these toxins (OK et al., 2009). In our study, this association was more significant.

STEC may be important in calves since Stx toxin can be involved in economic losses and important to the human healthy, since these animals could be carriers to humans. STEC is important for the herd since Stx can be responsible for economic losses and a threath to human health as animals can be carriers to humans. Cattle are considered to be the major reservoir of STEC worldwide (AIDAR-UGRINOVICH et al., 2007). Regions with high prevalence of STEC in dairy cattle usually do not have a high incidence of cases of human infections. One reason may be associated with the serogroup of $E$. coli (ARYA et al., 2008). In this work wealso identified non-STEC O-157 in healthy calves. These findings may mean that, at least in the Brazilian herd, these strains use healthy animals as carriers of these bacteria to humans. A growing number of non O-157 STEC serotypes have been isolated from animals and associated with human disease but these strains do not appear to be associated with clinical disease in cattle (KARMALI et al., 2010). In this report, 35 serogroups of E. coli were identified and the strains positive for eae/stx 1 were associated with bovine STEC and two of these serogroups are associated with illness in humans (O26 and O156) which are considered by other authors to be emergent pathogens for humans and bovine (ARYA et al., 2008; KARMALI et al., 2010). The diversity of serogroups detected in the present study could be attributed to the use of a complete set of $\mathrm{O}$ antisera (O1-O181), which was not used in other studies (CERQueIra et al., 1999; LeOMIL et al., 2003). Ehly is normally associated withSTEC isolated from calves (CoBbold; Desmarchelier, 2001). In Brazil, it was observed that strains positive for Ehly by PCR assays did not show activity on blood agar (IRINO et al., 2005). However, in our study, all E. coli-positive strains were positive on sheep blood agar and all of them were associated with other toxins and associated with important serogroups.

In conclusion, the high rate of STEC isolation and the diversity of STEC serogroups described herein point to dairy cattle as important reservoirs of STEC in our setting. A prevalence of STEC in cattle in Brazil and E. coli serogroups associated with human disease may indicate a source of potential public health risk in our community. The presence of virulence-associated traits in these isolates is currently being investigated. 


\section{ACKNOWLEDGEMENTS}

This work was supported by grants from the "Fundação de Amparo à Pesquisa do Estado de São Paulo -FAPESP (02/06522-4)". C. Moura was the recipient of a research fellowship from Conselho Nacional de Desenvolvimento Científicoe Tecnológico-CNPq. Wealso thank Erivaldo J. Silva for skillful technical assistance.

\section{REFERENCES}

AIDAR-UGRINOVKCH, L.; BLANCO, J.; BLANCO, M.; BLANCO, J.E.; LEOMIL, L.; DAHBI, G.; MORA, A.; ONUMA, D.L.; SILVEIRA, W.D.; PESTANA DE CASTRO, A.F. Serotypes, virulence genes, and intimin types of Shiga toxin-producing Escherichia coli (STEC) and enteropathogenic E. coli (EPEC) isolated from calves in São Paulo, Brazil. International Journal of Food Microbiology, v.115, p.297-306, 2007.

ARYA, G.; ROY, A.; CHOUDHARY, V.; YADAV, M.M.; JOSHI, C.G. Serogroups, atypical biochemical characters, colicinogeny and antibiotic resistance pattern of shiga toxin-producing Escherichia coli isolated from diarrhoeic calves in Gujarat, India. Zoonoses and Public Health, v.55, p.89-98, 2008.

BEUTIN, L.; PRADA, J.; ZIMMERMANN, S.; STEPHAN, R.; ÆRSKOV, I.; ÆRSKOV, F. Enterohemolysin, a new type of hemolysin produced by some strains of enteropathogenic Escherichia coli (EPEC). Zentralblatt für Bakteriologie, Mikrobiologie und Hygiene A, v.267, p.576-588, 1988.

BLANCO, J.; BLANCO, M.; ALONSO, M.P.; BLANCO, J.E.; GARABAL, J.I.; GONZALEZ, E.A. Serogroups of Escherichia coli strains producing cytotoxic necrotizing factors CNF1 and CNF2. FEMS Microbiology Letters, v.96, p.155-160, 1992.

CERQUEIRA, A.M.F.; GUTH, B.E.C.; JOAQUIM, R.M.; ANDRADE, J.R.C. High occurrence of Shiga toxinproducing Escherichia coli (STEC) in healthy cattle in Rio de Janeiro State, Brazil. Veterinary Microbiology, v.70, p.111-121, 1999.

COBBOLD, R.; DESMARCHELIER, P. Characterization and clonal relationships of Shiga-toxigenic Escherichia coli (VTEC) isolated from Australian dairy cattle. Veterinary Microbiology, v.79, p.323-335, 2001.

FIDOCK, D.A.; McNICHOLAS, P.A.; LEHRBACH, P.R. Nucleotide sequence of the F41 fimbriae subunit gene in Escherichia coli B41. Nucleic Acids Research, v.17, p.28492849, 1989.

GÜLER, L.; GÜNDÜZ, K.; OK, Ü. Virulence factors and antimicrobial susceptibility of Escherichia coli isolated from calves in Turkey. Zoonoses and Public Health, v.55, p.249-257, 2008.
IRINO, K.; KATO, M.A.M.F.; VAZ, T.M.I.; SOUZA, M.A.C.; CRUZ, A.S.; GOMES, T.A.T.; VIEIRA, M.; GUTH, B.E.C. Serotypes and virulence markers of Shiga toxin-producing Escherichia coli (STEC) isolated from dairy cattle in São Paulo State, Brazil. Veterinary Microbiology, v.105, p.29-36, 2005.

KARMALI, M.A.; GANNON, V.; SARGEANT, J.M. Verocytotoxin-producing Escherichia coli (VTEC). 2010. Veterinary Microbiology, v.140, p.360-370, 2010.

LEOMIL, L.; UGRINOVICH, A.L.; GUTH, B.E.C.; IRINO, K.; VETTORATO, M.P.; ONUMA, D.L.; DE CASTRO, A.F.P. Frequency of Shiga toxin-producing Escherichia coli (STEC) isolates among diarrheic and non-diarrheic calves in Brazil. Veterinary Microbiology, v.97, p.103-109, 2003.

OJENIYI, B.; AHRENS, P.; MEYLING, A. Detection of fimbrial and toxin genes in Escherichia coli and their prevalence in piglets with diarrhea. The application of colony hibridization assay polymerase chain reaction and phenotype assays. Journal of Veterinary Medicine B, v.41, p.49-59, 1994.

OK, M.; GÜLER, L.; TURGUT, K.; OK, Ü.; SEN, I.; GÜNDÜZ, K.; BIRDANE, M.F.; GÜZELBEKTES, H. The studies on the aetiology of diarrhoea in neonatal calves and determination of gene markers of Escherichia coli strains by multiplex PCR. Zoonoses and Public Health, v.56, p.94-101, 2009.

PATON, A.W.; PATON, J.C. Detection and characterization of shiga toxigenic Escherichia coli by using multiplex PCR assays for vt1, vt2, eaeA, enterohemorrhagic E. coli hlyA, $\mathrm{rfb}_{\mathrm{O} 111}$, and $\mathrm{rfb}_{\mathrm{O} 157}$. Journal of Clinical Microbiology, v.36, p.598-602, 1998.

ROOSSENDAAL, B.; GAASTRA, W.; GRAAF, F.K. The nucleotide sequence of the genes encoding the K99 subunit of enterotoxigenic Escherichia coli. FEMS Microbiology Letters, v.22, p.253-258, 1984.

SCHULTSZ, C.; POOL, G.J.; VAN KETEL, R.; DE WEVER B.; SPEELMAN, P.; DANKERT, J. Detection of enterotoxigenic Escherichia coli in stool samples by using nonradioactively labeled oligonucleotide DNA probes and PCR. Journal of Clinical Microbiology, v.32, p.2393-2397, 1994.

SO, M.; McCARTY, B.J. Nucleotide sequence of the bacterial transposon Tn1681 encoding a heat-stable (ST) toxin and its identification in enterotoxigenic Escherichia coli strains. Proceedings of the National Academy of Science USA, v.77, p.4011-4015, 1980.

YU, J.; KAPER, J.B. Cloning and characterization of the eae gene of enterohaemorragic Escherichia coli O157:H7. Molecular Microbiology, v.6, p.411-417, 1992.

Received on $27 / 9 / 10$

Accepted on 3/11/11 